Document downloaded from:

http://hdl.handle.net/10251/104863

This paper must be cited as:

Peris-Sayol, G.; Paya-Zaforteza, I.; Balasch Parisi, S.; Alós-Moya, J. (2017). Detailed Analysis of the Causes of Bridge Fires and Their Associated Damage Levels. Journal of Performance of Constructed Facilities. 31(3). doi:10.1061/(ASCE)CF.1943-5509.0000977

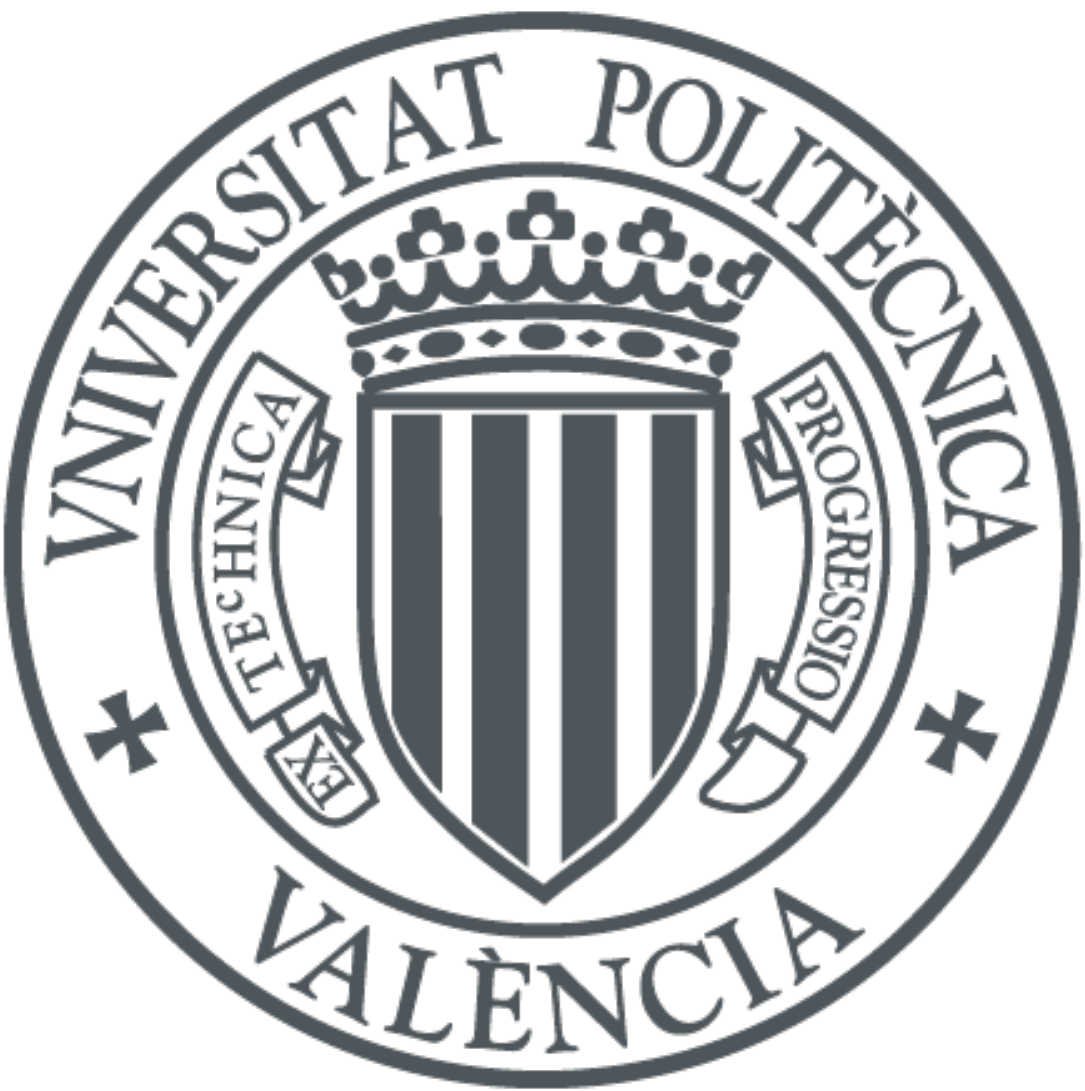

The final publication is available at

http://dx.doi.org/10.1061/(ASCE)CF.1943-5509.0000977

Copyright American Society of Civil Engineers

Additional Information 


\section{Please cite this paper as:}

Peris-Sayol G, Payá-Zaforteza I, Balasch-Parisi S, Alós-Moya J. (2017).

"Detailed Analysis of the Causes of Bridge fires and Their Associated Damage Levels". ASCE Journal of Performance and Constructed Facilities. Volume 31. Issue 3. June 2017. DOI:10.1061/(ASCE)CF.1943-5509.0000977 


\title{
Detailed analysis of the causes of bridge fires and their associated damage levels
}

\author{
G. Peris-Sayol $^{1}$, I. Paya-Zaforteza ${ }^{2}$, S. Balasch-Parisi ${ }^{3}$, J. Alós-Moya $^{4}$
}

\begin{abstract}
Although bridge fires pose a real threat, the topic is not covered in current design codes. This paper analyses information related to 154 cases of bridge fires, proposes classifying the damage levels suffered by a bridge during a fire, and establishes the main factors involved in bridge fire damage, which include: type of vehicle involved in the fire and its position, vertical clearance of the bridge, and the type of material composing the deck. The analysis shows that wooden bridges are the most vulnerable and that a tanker carrying gasoline under the bridge, or that is on the bridge and causes a serious spill under the bridge, is responsible for most of the fires that result in the collapse or demolition of the bridge.
\end{abstract}

Keywords: fire, bridge, statistical analysis, tanker fire, performance based approach.

${ }^{1}$ Research Asssitant. ICITECH, Universitat Politècnica de València. Camino de Vera s/n, 46071 Valencia, Spain. Email: guipesa2@upv.es

2 Associate Professor. ICITECH, Departamento de Ingeniería de la Construcción, Universitat Politècnica de València. Camino de Vera s/n, 46071 Valencia, Spain (corresponding autor). Email: igpaza@upv.es

${ }^{3}$ Professor. Dpto. de Estadística e Investigación Operativa Aplicadas y Calidad, Universitat Politècnica de València. Camino de Vera s/n, 46071 Valencia, Spain. Email: sbalasch@upv.es

${ }^{1}$ Research Assistant. ICITECH, Universitat Politècnica de València. Camino de Vera s/n, 46071 Valencia, Spain. Email: joalmo11@upv.es 
Please cite this paper as: Peris-Sayol G, Payá-Zaforteza I, Balasch-Parisi S, Alós-Moya J. (2017). "Detailed Analysis of the Causes of Bridge fires and Their Associated Damage Levels". ASCE Journal of Performance and Constructed Facilities. Volume 31. Issue 3. June 2017. DOI:10.1061/(ASCE)CF.1943-5509.0000977

\section{Introduction}

Recent research (Garlock et al. 2012; Wright et al. 2013; Mostaffei et al. 2014) has highlighted the importance of bridge fires and the failure of the current codes to provide design standards that adequately protect bridges against fires. In fact, the codes dealing with bridge design such as the Eurocode 1 part 2 (European Committee for Standardization -CEN- 2003) and the American Association of State Highway and Transportation Officials (AASHTO) standards (AASHTO 2015) ignore bridge fires altogether, and fire design standards such as the Eurocode 1 part 1-2 (CEN 2002) focus on buildings but do not cover bridges. The only standard containing information on how to deal with bridge fires is the National Fire Protection Association (NFPA) 502 "Standard for road tunnels, bridges and other limited access highways" (NFPA 2008). This standard contains some guidelines that apply to bridges over $300 \mathrm{~m}$ long, but the guidelines are along general lines and do not explain how to analyze a bridge under fire loads or how to protect them against fires. For example, Section 6.3 .3 of the NFPA 502 states, "For through truss and suspension bridges or elevated highways, an engineering analysis shall be prepared to determine acceptable risks, including possible collapse" but it does not provide any guidance on how to carry out the required engineering analysis.

This gap in the current codes together with the serious consequences of bridge fires has given rise to significant research in recent years. Research groups have proposed the use of fire curves (see e.g. Payá-Zaforteza and Garlock 2012), simplified methodologies based on the calculation of radiation heat fluxes (Quiel et al. 2015) or Computational Fluid Dynamics techniques (Alós-Moya et al. 2014, Peris-Sayol et al. 2014, 2015, Wright et al. 2013, Gong and Agraval 2014). In most of these studies the analysis focuses on fires caused by overturned tanker trucks below the bridge deck (Wright et al. 2013; Alós-Moya et al. 2014, Peris-Sayol et al. 2014, 2015), although Wright et al. 2013 and Gong and Agraval 2014 compared the effects of fires in different vehicles, including buses, heavy goods vehicles and tankers. Tankers were used as the fire load in these studies, since this type of vehicle has been responsible for the worst accidents, e.g. Hazel Park (2004), McArthur Maze (2007), Rouen (2012) and Ohio (2015) (see Table 1 for accident information). However, these studies do not give a detailed analysis of the causes and consequences of a wide range of fire events. 
Table 1. Examples of significant bridge fires

\begin{tabular}{|c|c|c|c|c|c|c|}
\hline Bridge/Location & Date & Cause of Fire & Bridge Material & Damage Description & $\begin{array}{l}\text { Bridge } \\
\text { Damage } \\
\text { Level }\end{array}$ & Reference \\
\hline $\begin{array}{l}\mathrm{I}-20 / \mathrm{I}-59 / \mathrm{I}-65 \\
\text { interchange in } \\
\text { Birmingham, AL, USA }\end{array}$ & $\begin{array}{l}\text { January 5, } \\
2002\end{array}$ & $\begin{array}{l}\text { A gasoline tanker overturned } \\
\text { and started a fire under the } \\
\text { bridge }\end{array}$ & $\begin{array}{l}\text { Composite deck (steel } \\
\text { girders }+ \text { reinforced concrete } \\
\text { slab) }\end{array}$ & $\begin{array}{l}\text { Main span sagged about } 3 \text { meters and the } \\
\text { bridge had to be replaced }\end{array}$ & 4 & $\begin{array}{l}\text { Alos et al } \\
(2014)\end{array}$ \\
\hline $\begin{array}{l}\text { Charilaos Trikoupis } \\
\text { (Rio-Antirrio) Bridge, } \\
\text { Greece }\end{array}$ & $\begin{array}{l}\text { January } \\
28,2005\end{array}$ & $\begin{array}{l}\text { The cause of the fire is not } \\
\text { ascertained, but it is believed } \\
\text { that it could have been caused } \\
\text { by a lightning }\end{array}$ & $\begin{array}{l}\text { Cable-stayed bridge with a } \\
\text { composite deck }\end{array}$ & $\begin{array}{l}\text { One of cable caught fire and collapse, } \\
\text { damaging the adjacent cable and crushing } \\
\text { onto the deck }\end{array}$ & 3 & $\begin{array}{l}\text { Giuliani et al. } \\
\text { (2012) }\end{array}$ \\
\hline $\begin{array}{l}\text { Brooklyn Queens } \\
\text { Expressway close to } \\
\text { Roosevelt avenue, New } \\
\text { York, NY, USA }\end{array}$ & $\begin{array}{l}\text { January } \\
16,2006\end{array}$ & $\begin{array}{l}\text { A gasoline tanker crashed } \\
\text { under the bridge }\end{array}$ & $\begin{array}{l}\text { Composite deck. The bridge } \\
\text { was under construction and } \\
\text { only the steel girders were } \\
\text { on place. The concrete slab } \\
\text { was not built. }\end{array}$ & $\begin{array}{l}\text { Complete collapse of the girders which fell } \\
\text { on the freeway below }\end{array}$ & 5 & $\begin{array}{l}\text { NYtimes } \\
(2006)\end{array}$ \\
\hline Mezcala Bridge, Mexico & $\begin{array}{l}\text { March 17, } \\
2007\end{array}$ & $\begin{array}{l}\text { A coconut-carrying truck } \\
\text { collided with two school buses } \\
\text { and started a fire }\end{array}$ & $\begin{array}{l}\text { Cable-stayed bridge with a } \\
\text { steel deck }\end{array}$ & $\begin{array}{l}\text { Failure of one stay and limited damage to an } \\
\text { adjacent stay }\end{array}$ & 3 & $\begin{array}{l}\text { Feng and Cai } \\
(2009)\end{array}$ \\
\hline $\begin{array}{l}\text { I-80/880 interchange } \\
\text { (MacArthur Maze) in } \\
\text { Oakland, CA, USA }\end{array}$ & $\begin{array}{l}\text { April 29, } \\
2007\end{array}$ & $\begin{array}{l}\text { A gasoline tanker crashed } \\
\text { under the bridge }\end{array}$ & $\begin{array}{l}\text { Composite deck (steel } \\
\text { girders + reinforced concrete } \\
\text { slab) supported by } \\
\text { reinforced concrete columns }\end{array}$ & A $50 \mathrm{~m}$ section of the interchange collapsed & 5 & $\begin{array}{l}\text { Noble et al. } \\
(2008) \\
\text { Astaneh et al. } \\
(2009)\end{array}$ \\
\hline $\begin{array}{l}\text { Bridge over the I-75 } \\
\text { highway near Hazel } \\
\text { Park, MI, USA }\end{array}$ & $\begin{array}{l}\text { July } 15 \\
2009\end{array}$ & $\begin{array}{l}\text { A gasoline tanker truck struck } \\
\text { an overpass on the I-75 }\end{array}$ & $\begin{array}{l}\text { Composite deck (steel } \\
\text { girders }+ \text { reinforced concrete } \\
\text { slab) }\end{array}$ & $\begin{array}{l}\text { Complete collapse of the bridge which fell } \\
\text { on the freeway below }\end{array}$ & 5 & $\begin{array}{l}\text { Garlock et. al } \\
(2012)\end{array}$ \\
\hline $\begin{array}{l}\text { Freeway } 80 \text { under } \\
\text { Paramount Boulevard, } \\
\text { Montebello, CA, USA }\end{array}$ & $\begin{array}{l}\text { December } \\
14,2011\end{array}$ & $\begin{array}{l}\text { A gasoline tanker caught fire } \\
\text { under the bridge }\end{array}$ & $\begin{array}{l}\text { Concrete girders with a } \\
\text { reinforced concrete slab on } \\
\text { top }\end{array}$ & $\begin{array}{l}\text { Generalized spalling in the structure and } \\
\text { damage in the reinforcing bars. The bridge } \\
\text { was demolished }\end{array}$ & 4 & $\begin{array}{l}\text { Giuliani et al. } \\
(2012)\end{array}$ \\
\hline $\begin{array}{l}\text { Highway 57, Dormagen, } \\
\text { Germany }\end{array}$ & $\begin{array}{l}\text { February } \\
14,2012\end{array}$ & $\begin{array}{l}\text { Plastic stored under the bridge } \\
\text { caught fire }\end{array}$ & Concrete slab & $\begin{array}{l}\text { Generalized spalling in a section of the } \\
\text { structure. The bridge was demolished }\end{array}$ & 4 & $\begin{array}{l}\text { Bergerhausen } \\
\text { and Priestaff } \\
(2012)\end{array}$ \\
\hline
\end{tabular}


Please cite this paper as: Peris-Sayol G, Payá-Zaforteza I, Balasch-Parisi S, Alós-Moya J. (2017). "Detailed Analysis of the Causes of Bridge fires and Their Associated Damage Levels". ASCE Journal of Performance and Constructed Facilities. Volume 31. Issue 3. June 2017. DOI:10.1061/(ASCE)CF.1943-5509.0000977

\begin{tabular}{|c|c|c|c|c|c|c|}
\hline $\begin{array}{l}\text { Pont Mathilde, Rouen, } \\
\text { France }\end{array}$ & $\begin{array}{l}\text { October } \\
29,2012\end{array}$ & $\begin{array}{l}\text { A tanker overturned and caught } \\
\text { fire on the bridge. The fuel spill } \\
\text { reached some trucks parked } \\
\text { under the bridge that also } \\
\text { caught fire }\end{array}$ & Steel deck with I-girders & $\begin{array}{l}\text { Severe deformation of the girder in the } \\
\text { section close to the fire. A section of the } \\
\text { bridge had to be demolished }\end{array}$ & 4 & $\begin{array}{l}\text { Godart et al. } \\
(2015) \\
\text { Le Figaro } \\
(2015)\end{array}$ \\
\hline $\begin{array}{l}\text { Interchange I- } 85 / \text { route } \\
\text { 23-322, Harrisburg, PA, } \\
\text { USA }\end{array}$ & $\begin{array}{l}\text { May 9, } \\
2013\end{array}$ & A diesel tanker crashed & $\begin{array}{l}\text { Two bridges in the } \\
\text { intersection got involved in } \\
\text { the fire, both with a } \\
\text { composite deck (steel } \\
\text { girders + reinforced concrete } \\
\text { slab) }\end{array}$ & $\begin{array}{l}\text { The bridge above the fire had to be } \\
\text { demolished. The bridge on which the tanker } \\
\text { blazed could be repaired. }\end{array}$ & 4 & $\begin{array}{l}\text { Le High } \\
\text { Walley Live } \\
\text { (2013) } \\
\text { The Sentinel } \\
(2013)\end{array}$ \\
\hline $\begin{array}{l}\text { Ed Koch Queensboro } \\
\text { Bridge, NY, USA }\end{array}$ & $\begin{array}{l}\text { August } \\
16,2013\end{array}$ & $\begin{array}{l}\text { A } 12-\mathrm{m} \text { tractor-trailer traveling } \\
\text { on the outbound lower level of } \\
\text { the bridge caught fire }\end{array}$ & $\begin{array}{l}\text { Five-span cantilever truss } \\
\text { bridge }\end{array}$ & $\begin{array}{l}\text { Two stringers of the upper deck were } \\
\text { severely deformed and damaged. }\end{array}$ & 2 & $\begin{array}{l}\text { Gong and } \\
\text { Agrawal } \\
(2015)\end{array}$ \\
\hline $\begin{array}{l}\text { Overpass in El Cairo, } \\
\text { Egypt }\end{array}$ & $\begin{array}{l}\text { February } \\
11,2014\end{array}$ & $\begin{array}{l}\text { Gas cylinders in the shanty } \\
\text { town underneath exploded }\end{array}$ & $\begin{array}{l}\text { Composite deck (steel } \\
\text { girders }+ \text { reinforced concrete } \\
\text { slab) supported by steel } \\
\text { columns }\end{array}$ & $\begin{array}{l}\text { One of the steel columns collapsed due to } \\
\text { the high temperature. Three sections of the } \\
\text { bridge completely collapsed. }\end{array}$ & 5 & $\begin{array}{l}\text { Yahoo News } \\
(2014) \\
\text { Ahram } \\
(2014)\end{array}$ \\
\hline $\begin{array}{c}\text { Ranchero Road overpass } \\
\text { onto the I-15, Hesperia, } \\
\text { CA, USA }\end{array}$ & $\begin{array}{l}\text { May 5, } \\
2014\end{array}$ & $\begin{array}{l}\text { Workers accidentally ignited } \\
\text { the wooden formwork of a } \\
\text { concrete bridge under } \\
\text { construction }\end{array}$ & $\begin{array}{l}\text { Wooden formwork } \\
\text { supported by steel girders } \\
\text { (the bridge deck was under } \\
\text { construction) }\end{array}$ & $\begin{array}{l}\text { Collapse of the steel girders which fell on } \\
\text { the freeway below. }\end{array}$ & 5 & $\begin{array}{l}\text { Los Angeles } \\
\text { Times (2014) } \\
\text { CBS Los } \\
\text { Angeles } \\
(2014)\end{array}$ \\
\hline $\begin{array}{l}\text { I-65/Peytonsville Road, } \\
\text { Franklin,TN, USA }\end{array}$ & $\begin{array}{l}\text { August } \\
15,2014\end{array}$ & $\begin{array}{l}\text { A gasoline tanker ran into a } \\
\text { pier of the overpass and } \\
\text { exploded }\end{array}$ & $\begin{array}{l}\text { Two overpasses were } \\
\text { affected, one with concrete } \\
\text { girders, another under } \\
\text { construction with steel } \\
\text { girders, both with a } \\
\text { reinforced concrete slab } \\
\text { resting on the girders. }\end{array}$ & $\begin{array}{l}\text { Severe deformation of the steel girders and } \\
\text { significant spalling in the concrete bridge. } \\
\text { Both bridges were demolished. }\end{array}$ & 4 & $\begin{array}{l}\text { WSMV } \\
(2014) \\
\text { The } \\
\text { Tennessean } \\
(2014)\end{array}$ \\
\hline $\begin{array}{l}\text { I270/I-70 Ramp, Ohio, } \\
\text { USA }\end{array}$ & $\begin{array}{l}\text { July } 1 \\
2015\end{array}$ & $\begin{array}{l}\text { An ethanol tanker fire caught } \\
\text { fire under the bridge }\end{array}$ & Reinforced concrete slab & $\begin{array}{l}\text { Generalized concrete spalling. The } \\
\text { reinforcing bars broke and fell due to high } \\
\text { temperatures. The bridge was demolished }\end{array}$ & 4 & $\begin{array}{l}\text { 10TV (2015) } \\
\text { NBC4 (2015) }\end{array}$ \\
\hline
\end{tabular}


Please cite this paper as: Peris-Sayol G, Payá-Zaforteza I, Balasch-Parisi S, Alós-Moya J. (2017). "Detailed Analysis of the Causes of Bridge fires and Their Associated Damage Levels". ASCE Journal of Performance and Constructed Facilities. Volume 31. Issue 3. June 2017. DOI:10.1061/(ASCE)CF.1943-5509.0000977

In this context, this paper studies the relationship between the characteristics of a fire event, the geometrical and structural properties of the bridge and the damage suffered by the bridge as a consequence of the fire. The study presented here is based on the analysis of 154 cases of bridge fires between 1997 and 2015 and complements previous work (Naser and Kodur 2015). The study aims at finding the bridge types most vulnerable to fires and at establishing the fire scenarios that should be considered when studying a bridge's fire response. We also aim to set the foundations for the development of a performance-based approach for including fire-protection measures in bridge design. By focusing on the analysis of engineering failures, the paper also aims to learn from previous disasters and to extend the engineering aspects considered by other research groups (see e.g. Calderón et al. 2009; Dai et al. 2015; Lee and Wang 2015; Carretero-Ayuso et al. 2015). This paper is organized as follows. Firstly the methodology used to define the parameters that characterize bridge fires is described. Then a statistical analysis of the relationship between all the parameters considered is carried out and finally the main conclusions of the research are given.

\section{Data collection}

The work of Garlock et al. (2012), who collected the available information on 11 bridge fires, was used as the starting point for the present study. The original 11 cases were expanded into a total of 154 by adding others from an extensive search of information published in specialist journals, reports by bridge management authorities and information published in the news. This information was assembled into a data base that included the following fields: identifying name of bridge fire, bridge site, deck material, bridge structural system, bridge span and width, cause of fire, and damage level caused by the fire. In the cases of fires caused by a product in storage or being transported by a truck, the fuel type was also specified. In the cases of fires caused by tanker trucks, the tanker truck position was also detailed. Further details of all these fields are given below.

\section{Bridge site}

Three types of bridge site were considered: 
Please cite this paper as: Peris-Sayol G, Payá-Zaforteza I, Balasch-Parisi S, Alós-Moya J. (2017). "Detailed Analysis of the Causes of Bridge fires and Their Associated Damage Levels". ASCE Journal of Performance and Constructed Facilities. Volume 31. Issue 3. June 2017. DOI:10.1061/(ASCE)CF.1943-5509.0000977

1) Rural: involving secondary roads with little traffic.

2) Urban: the bridge is part of a city road network.

3) Suburban: on accesses to cities or industrial estates.

\section{Deck material}

Four categories were included: reinforced or prestressed concrete, steel, composite steel-concrete, and wooden structures.

\section{Structural system}

The following types were considered: cable-stayed bridges, suspension bridges, arch bridges, truss bridges, box girder bridges and I-girder bridges.

Note that in this study, the bridge structural system and the bridge material are considered as two independent fields. That means that, for example, results related to I-girder bridges apply to this structural system regardless of the construction material used in the bridge.

\section{Bridge span and width}

Bridge spans and widths were mostly obtained from the data included in accident investigations. In cases where this information was not available we resorted to Google Earth to estimate these dimensions.

\section{Cause offire}

The initiating fire element is one of vital importance in analyzing fire effects. The present study considers the following seven fire causes:

1) Cars: fire caused by a blazing car: In such cases the fire is fed by both the car components and its fuel, which in $99 \%$ of cases is composed of gasoline or diesel (Society of Fire Protection Engineers -SFPE- 2002).

2) Trucks: Fire caused by a truck carrying goods other than highly flammable fuels. In some cases only the truck catches fire and in others the cargo also.

3) Tanker trucks: this type also includes trains transporting highly flammable liquid or gas fuels. 
Please cite this paper as: Peris-Sayol G, Payá-Zaforteza I, Balasch-Parisi S, Alós-Moya J. (2017). "Detailed Analysis of the Causes of Bridge fires and Their Associated Damage Levels". ASCE Journal of Performance and Constructed Facilities. Volume 31. Issue 3. June 2017. DOI:10.1061/(ASCE)CF.1943-5509.0000977

4) Electrical problems: in many cases electrical equipment is carried over bridges, involving the risk of short circuits and consequent fire in the structure or its surroundings.

5) Stored materials: the space under a bridge is often used as a store and the materials sometimes catch fire and damage the bridge structure.

6) Forest fires or arson: bridges caught in forest fires or deliberately torched by arsonists.

7) Others: includes those that do not fit into any of the above categories, such as formwork fires or those whose cause has not been determined.

\section{Fuel types}

This category was considered in cases in which the fire was clearly due to the combustion of a product in storage or being transported by truck. The following fuel types were studied: gasoline, diesel fuel, other hydrocarbons, alcohol-based liquids, tires, plastics and other solid materials.

\section{Position of tanker truck}

When the initiating fire element is a tanker, the positions of the tanker and the fuel spill define the position of the fire load in relation to the bridge structure. This fire load position is very important to determine which parts of the bridge will be affected by the fire and, therefore, to study the bridge damage level. In this research the following four categories of fire load position were considered.

1) Tanker on the bridge with no fuel spillage onto lower sections.

2) Tanker under the bridge.

3) Tanker on the bridge with considerable fuel spillage causing a fire in lower sections.

4) Tanker near but not in contact with the bridge.

\section{Damage levels}

The fire damage caused to the bridge was classified in five levels: from the lowest (Damage Level 1) to the highest (Damage Level 5) (see below). Figure 1 shows some examples that illustrate these bridge damage levels. 
Please cite this paper as: Peris-Sayol G, Payá-Zaforteza I, Balasch-Parisi S, Alós-Moya J. (2017). "Detailed Analysis of the Causes of Bridge fires and Their Associated Damage Levels". ASCE Journal of Performance and Constructed Facilities. Volume 31. Issue 3. June 2017. DOI:10.1061/(ASCE)CF.1943-5509.0000977
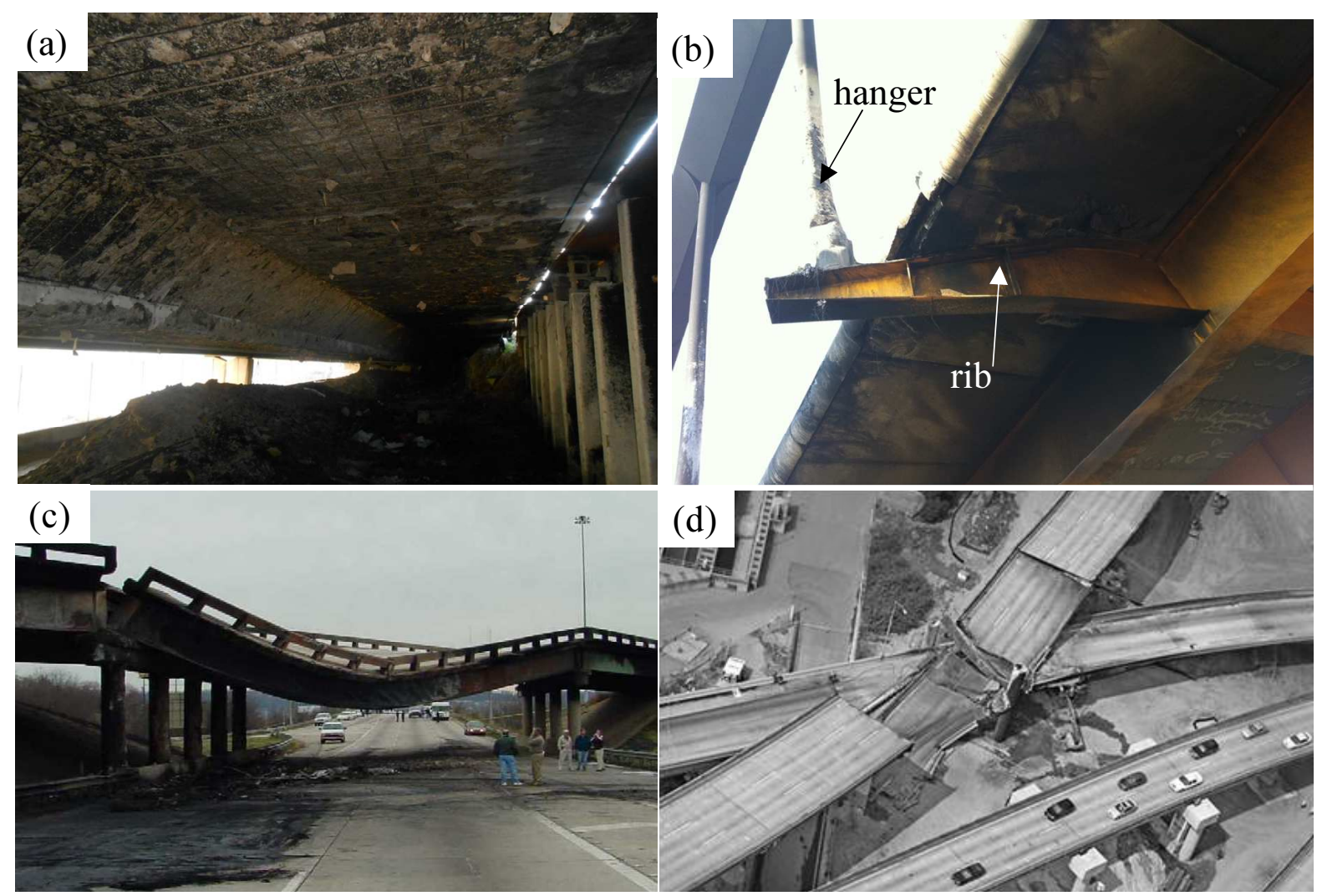

Fig. 1. Some examples of bridge damage levels. (a) Damage level 2: concrete spalling after a fire in a prestressed concrete bridge in Madrid, Spain. Image courtesy of Ines Ingenieros Consultores. (b) Damage Level 3: hanger and rib of a bowstring bridge in Castilla y León (Spain) that had to be replaced. Image courtesy of A.T.P. Ingeniería S.L.. (b) Damage Level 4: I-20/I-59/I-65 interchange in Birmingham, Alabama, USA. Image courtesy of the Alabama Department of Transportation (c) Damage Level 5: Collapse of a portion of the MacArthur Maze in Oakland, California, USA. Image courtesy of Robert Campbell.

\section{Damage Level 1: Superficial damage}

Minimum damage, mostly affecting deck surface or lower deck or equipment with no structural damage.

\section{Damage Level 2: Slight damage}

Structural damage to bridge that can be repaired without replacing main structural elements. For example:

a) Concrete spalling that does not affect reinforcement.

b) Blackening or reddening of concrete.

c) Slight damage to main beams, which do not need to be replaced. 
Please cite this paper as: Peris-Sayol G, Payá-Zaforteza I, Balasch-Parisi S, Alós-Moya J. (2017). "Detailed Analysis of the Causes of Bridge fires and Their Associated Damage Levels". ASCE Journal of Performance and Constructed Facilities. Volume 31. Issue 3. June 2017. DOI:10.1061/(ASCE)CF.1943-5509.0000977

\section{Damage Level 3: Partial damage}

This category sustains damage that involves the replacement of main structural elements, including exposed and damaged concrete reinforcement that needs repair.

\section{Damage Level 4: Massive damage}

The bridge sustains considerable damage but does not collapse. However, due to the uncertainty about its residual strength and the possibility of repair, it is demolished and a new structure is built. For example:

a) Steel structures: large irreparably buckled or deformed areas.

b) Concrete structures: massive spalling together with exposed and irreparable reinforcement.

\section{Damage Level 5: Structural collapse}

Total or partial bridge collapse.

The last column in Table 1 shows the damage levels sustained in fires by 15 bridges.

\section{Statistical analysis}

The Analysis of Variance (ANOVA) statistical test was the primary tool in the analysis of the data collected from the 154 bridge fires. This test compares the means of three or more groups in response to one or several variables and is used to determine the impact of independent variables (e.g. the bridge structural system or the deck material) on the dependent variable (bridge damage level) in a regression analysis. This impact is given by a coefficient known as the $p$-value. Low $p$-values indicate a significant influence. Further details on the ANOVA can be found in the specialized literature (see e.g. Kutner et al. 2005) and are not given here. All the analyses were run on Statgraphics software (StatPoint Tech. 2010). When the independent variables analyzed were found to have a significant influence on the bridge damage level, a graphical comparison of the bridge damage values was carried out using Tukey's intervals, which compare mean values of the analyzed variables. When the Tukey intervals of two variables do not overlap, this indicates that they are significantly different to each other. When they do overlap there is no significant difference. 


\section{Deck material}

The first ANOVA was on the influence of deck material on the bridge's damage level. The $p$-value of this analysis was 0.0000 , which shows a significant influence. A graph of the results can be seen in Figure 2.

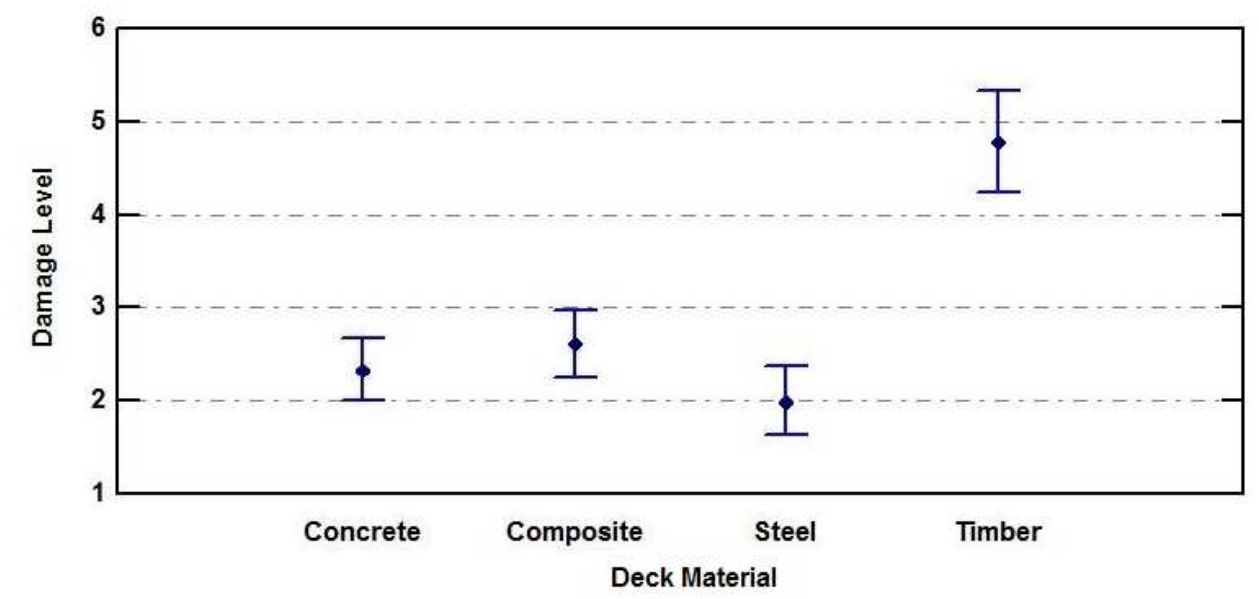

Fig. 2. Relation between bridge damage level and type of deck material. Tukey's intervals and average damage levels.

The main conclusions that can be drawn from this analysis are:

1) Wooden bridges have much worse behavior against fires than those made of other materials. This is shown by the fact that the average damage level is 4.8 , the Tukey intervals do not overlap those of the other materials, and that $79 \%$ of wooden bridges collapsed in the event of a fire. This worse behavior is due to wood being combustible, unlike steel or concrete, so that a small heat source can cause a conflagration and collapse and no external heat source is needed to propagate the fire.

The average damage levels for composite, concrete and steel bridges are 2.6, 2.3 and 2.0, respectively, and the corresponding Tukey intervals overlap. It can therefore be concluded that there are no statistically significant differences in the fire response of these types of bridge. Composite bridges were found to sustain higher average damage than the other groups (except wooden bridges). It should also be pointed out that even though some concrete bridges have been seriously damaged by fires (e.g. extensive concrete spalling, rupture of reinforcing bars) and had to be demolished and reconstructed, no case was found of a 
Please cite this paper as: Peris-Sayol G, Payá-Zaforteza I, Balasch-Parisi S, Alós-Moya J. (2017). "Detailed Analysis of the Causes of Bridge fires and Their Associated Damage Levels". ASCE Journal of Performance and Constructed Facilities. Volume 31. Issue 3. June 2017. DOI:10.1061/(ASCE)CF.1943-5509.0000977

concrete bridge that collapsed during a fire. However, there have been nine cases of composite steel-concrete bridges that collapsed during their construction or once finished due to the high temperatures reached during a fire event, including the examples of Brooklyn Queens Expressway in New York (2006), MacArthur Maze in Oakland (2007) and Hazel Park, Detroit (2009), as can be seen in Table 1. However, it should also be pointed out that several bridges (see e.g. in Table 1 the Hesperia Bridge fire in 2014) collapsed during construction due to fires in the wooden formwork used as concrete molds. These collapses occurred in a very short period that did not give the fire services time to intervene. Note also that the steel bridges that caught fire crossed a river or an important valley (see e.g. the Queensboro bridge fire and the Mezcala Bridge fire in Table 1). In these cases the fire cannot be provoked by a tanker truck under the bridge, which is the most harmful fire load as will be discussed in the subsection "Origin of fire". This fact explains why the average damage level of steel bridges is lower than in concrete and composite bridges even if concrete has a better fire performance than steel.

\section{Origin of fire}

In the previous section it was seen that wooden bridges are very prone to collapse in a fire, regardless of the cause, due to the high calorific value of wood. The following analyses therefore exclude data from wooden bridge fires, since whatever the cause of the fire, these bridges almost inevitably collapse.

A study was carried out on whether there was a relationship between the fire's origin and the damage caused, and if so, the causes that produce the greatest damage and that should therefore receive the closest attention in the study. From the results obtained, the types of fires in steel or concrete bridges that can cause the most damage will be ascertained.

For this study a p-value of 0.0000 was obtained, which indicates that in fact there is a statistically significant relationship between the cause of the fire and the damage sustained by the bridge. This relationship can be seen in Figure 3 by means of a graphical representation of the Tukey intervals. 


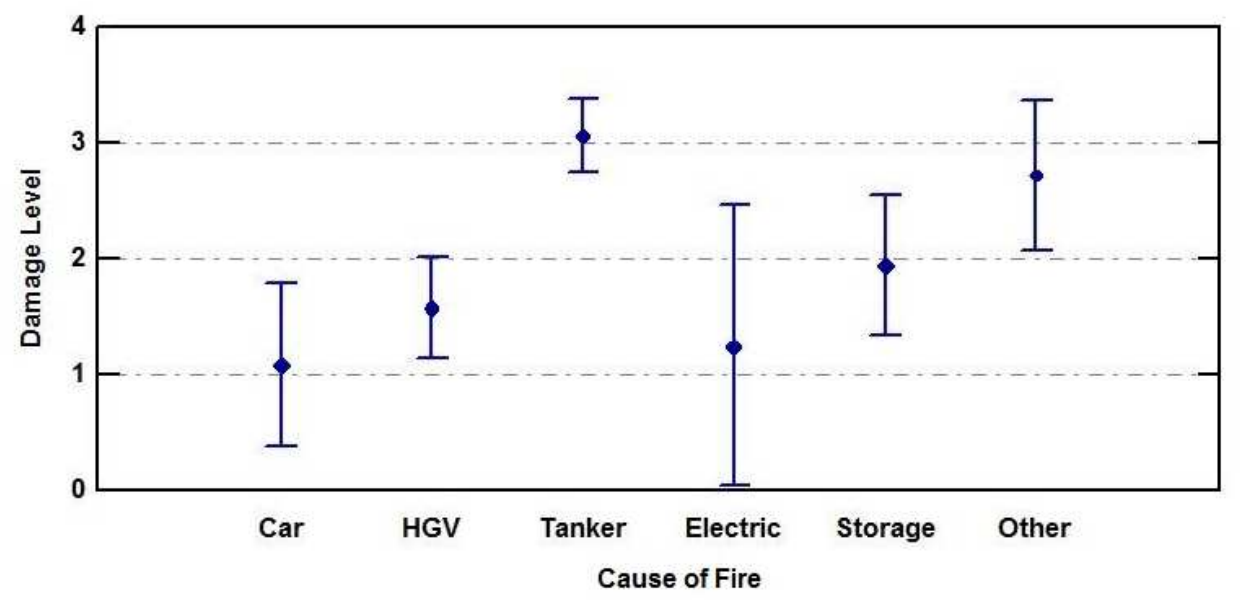

Fig. 3. Relationship between the bridge damage level and the cause of the fire. Tukey's intervals and average damage levels.

Figure 3 shows that blazing tanker trucks cause the most severe damage levels (average 3.1) due to the high calorific value of the products they transport. Fires in cars and heavy goods vehicles (HGV) cause slight damage (average 1.1 and 1.6, respectively) and do not usually reach the main bridge structure, and so it can be easily repaired. The damage caused by materials stored under a bridge depends on the volume of the stored material and the vertical clearance. Severe damage is only caused by goods of high calorific value combined with high heat release rates in a comparatively short time. These factors, together with a small vertical clearance between the fire and the deck can mean that the flames reach the bridge structure. These circumstances actually happened in the fire that broke out in plastic pipes stored under a highway bridge in Dormagen (Germany) in 2012. The reduced clearance (around $2.5 \mathrm{~m}$ ) between the top of the stored pipes and the underside of the bridge allowed the flames to reach the deck and caused general spalling of the concrete. As a result the deck had to be pulled down and a new one constructed.

The "Others" category includes a wide variety of fire causes corresponding to isolated (nonrecurrent) events that result in a wide variety of damage levels. An illustrative example is the fire in a motorway overpass in Cairo (Egypt) in 2012 (see Table 1), when a gas pipe fractured and caused a fire near some structurally critical piers, one of which gave way and led to the failure of the rest of the structure.

\section{Fires caused by burning tanker trucks}


Please cite this paper as: Peris-Sayol G, Payá-Zaforteza I, Balasch-Parisi S, Alós-Moya J. (2017). "Detailed Analysis of the Causes of Bridge fires and Their Associated Damage Levels". ASCE Journal of Performance and Constructed Facilities. Volume 31. Issue 3. June 2017. DOI:10.1061/(ASCE)CF.1943-5509.0000977

As seen in the previous section, tanker truck fires cause the most severe damage to bridge structures. They also often give rise to long-term traffic restrictions with their associated direct and indirect costs, in addition to the cost of repairing or reconstructing the bridge. For example, the collapse of a section of the MacArthur Maze in California required a total of $\$ 9$ million to repair the damage (Bulwa et al. 2007, Astaneh-Asl et al. 2009). However, the closure of the Maze was estimated to have a total economic impact on the San Francisco Bay Area of \$6 million dollars a day (Chung et al. 2008). A total of 58 cases were collected in which the blaze was caused by a fuel tanker, with an average of three cases a year (See Fig.4).

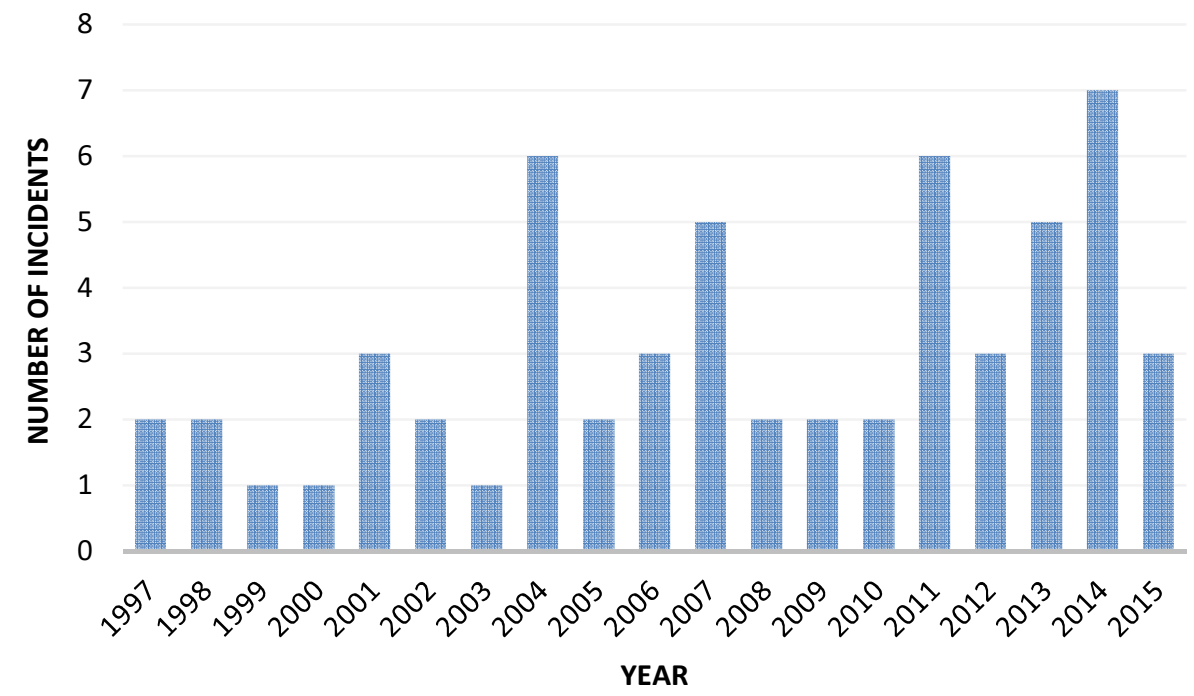

Fig. 4. Number of incidents involving tanker trucks per year

Due to their importance, this section studies the factors that influence the damage levels in this type of bridge fire. An ANOVA analysis was carried out on the damage levels caused by: bridge geometry, deck material, the fuel being transported by the tanker, and the truck's position in relation to the bridge. The results are given in Table 2 and show that the only parameters that have a significant effect on the damage levels of tanker-induced fires are the type of fuel being carried and the tanker truck position, with p-values of 0.0078 and 0.0211 , respectively. Further details on the influence of the fuel type and the bridge structural system on the bridge damage level are given next. 
Please cite this paper as: Peris-Sayol G, Payá-Zaforteza I, Balasch-Parisi S, Alós-Moya J. (2017). "Detailed Analysis of the Causes of Bridge fires and Their Associated Damage Levels". ASCE Journal of Performance and Constructed Facilities. Volume 31. Issue 3. June 2017. DOI:10.1061/(ASCE)CF.1943-5509.0000977

Table 2. Results of the ANOVA analysis for bridge damage level. Note that the ANOVA analysis considered 50 out of the 58 cases of bridge fires caused by a tanker. This is due to the fact that the authors could find the values of all the variables involved in the analysis in 50 cases.

\begin{tabular}{lccccc}
\hline & $\begin{array}{c}\text { Sum of } \\
\text { squares }\end{array}$ & $\begin{array}{c}\text { Degrees of } \\
\text { freedom }\end{array}$ & Mean Square & F- ratio & p-value \\
\hline Covariables & & & & & \\
$\quad$ Span & 1.5517 & 1 & 1.5517 & 1.29 & 0.2643 \\
$\quad$ Width & 2.62376 & 1 & 2.62376 & 2.18 & 0.1491 \\
Principal effects & & & & & \\
A: Bridge site & 2.48188 & 2 & 1.24094 & 1.03 & 0.3678 \\
$\quad$ B: Structural system & 2.22784 & 2 & 1.11392 & 0.92 & 0.4064 \\
$\quad$ C: Deck material & 0.393899 & 2 & 0.196949 & 0.16 & 0.8499 \\
$\quad$ D: Fuel type & 16.766 & 3 & 5.58866 & 4.64 & 0.0078 \\
$\quad$ E: Tanker truck & 13.2909 & 3 & 4.4303 & 3.67 & 0.0211 \\
position & 42.195 & 35 & 1.20557 & & \\
Residuals & 82.0 & 49 & & & \\
Total & & & & \\
\hline
\end{tabular}

\section{Influence of the fuel type on the damage level}

Figure 5 gives the results of the analysis of the influence of fuel type on damage levels. The Tukey intervals associated with gasoline, diesel fuel and alcohol-based fuels such as ethanol and methanol overlap, so that it cannot be concluded that fuel type has a significant influence on damage. The absence of significant differences could be due to the small number of fires caused by alcohol-based liquids and diesel fuel and the higher variability in their damage levels, as compared to those caused by gasoline (Fig. 5). 


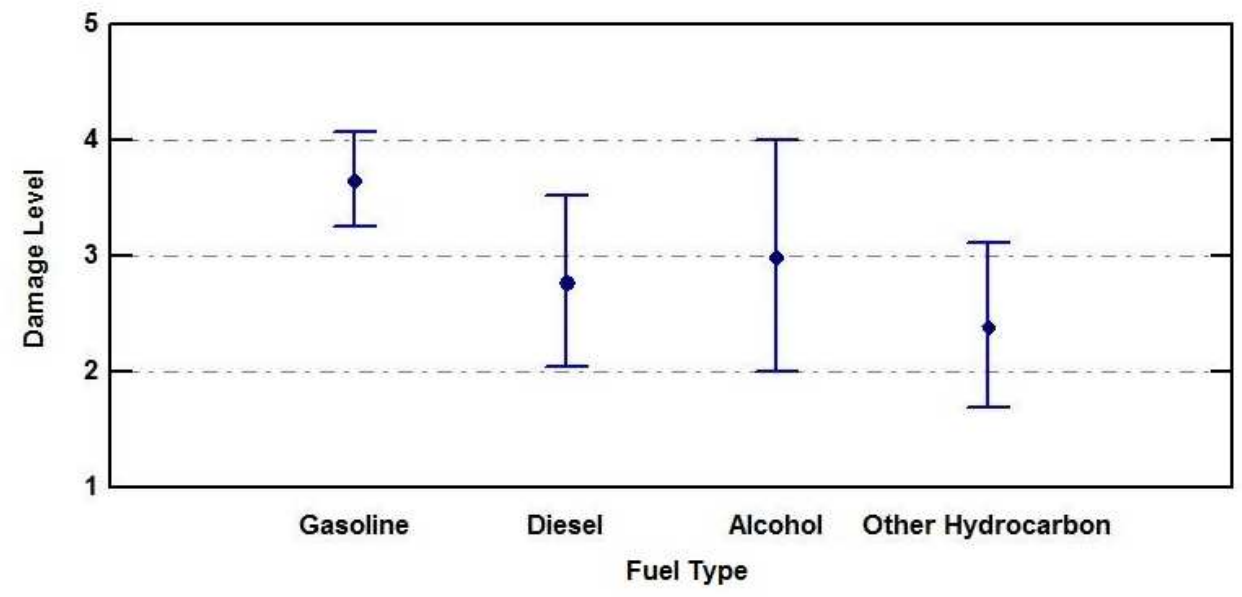

Fig. 5. Relation between bridge damage level and the type of fuel carried by the tanker. Tukey's intervals and average damage levels.

Fire events due to tankers carrying gasoline caused average damage levels of 3.7, which was higher than those due to diesel fuel (2.8), alcohol-based fuels (3.0) and other types of hydrocarbons (2.4). The more severe damage caused by gasoline tanker fires is explained by the fuel combustion studies contained in the SFPE Handbook (SFPE 2002). These studies found that gasoline has a higher heat release rate than other types of fuel and that, unlike diesel fuel, it is highly flammable at ambient temperatures. According to the data contained in the SFPE (2002), gasoline's heat release rate is 2400 $\mathrm{kW} / \mathrm{m}^{2}$, while that of diesel fuel is $1950 \mathrm{~kW} / \mathrm{m}^{2}$. This means that the temperatures reached in the bridge structure are higher and more severe damage is sustained from a gasoline tanker fire than from one carrying diesel or another type of fuel. In this regard it should be pointed out that:

- More than half of the tankers that caused fires were carrying gasoline (56\%) as against $17 \%$ that contained diesel fuel, $18 \%$ carried other types of hydrocarbons such as fuel oil, crude oil or petroleum, and $8 \%$ carried alcohol-based fuels such as ethanol or methanol.

- The fuel quantities carried in the tankers in the cases analyzed was between $30-35 \mathrm{~m}^{3}$.

\section{Influence of the tanker truck position on the damage level}

Figure 6 shows the damage levels associated with the position of the blazing tanker. It can be seen that when the tanker is either immediately under the bridge or actually on the bridge but there is significant oil spillage under the bridge, the damage level is significantly higher (average values 3.4 and 3.3, respectively). This is due in such cases to the flames coming into contact with the bridge 
Please cite this paper as: Peris-Sayol G, Payá-Zaforteza I, Balasch-Parisi S, Alós-Moya J. (2017). "Detailed Analysis of the Causes of Bridge fires and Their Associated Damage Levels". ASCE Journal of Performance and Constructed Facilities. Volume 31. Issue 3. June 2017. DOI:10.1061/(ASCE)CF.1943-5509.0000977

structure and hot gases accumulating near the structure, which raises the temperature higher than when the tanker is on top of the bridge and no fuel spills underneath. When fires break out close to bridge structures without actually touching them they do not cause serious damage. Therefore, special attention should be paid to bridge drainage systems in order to prevent fuel spills from accumulating under the bridge, as these pools can significantly increase structural damage when they ignite.

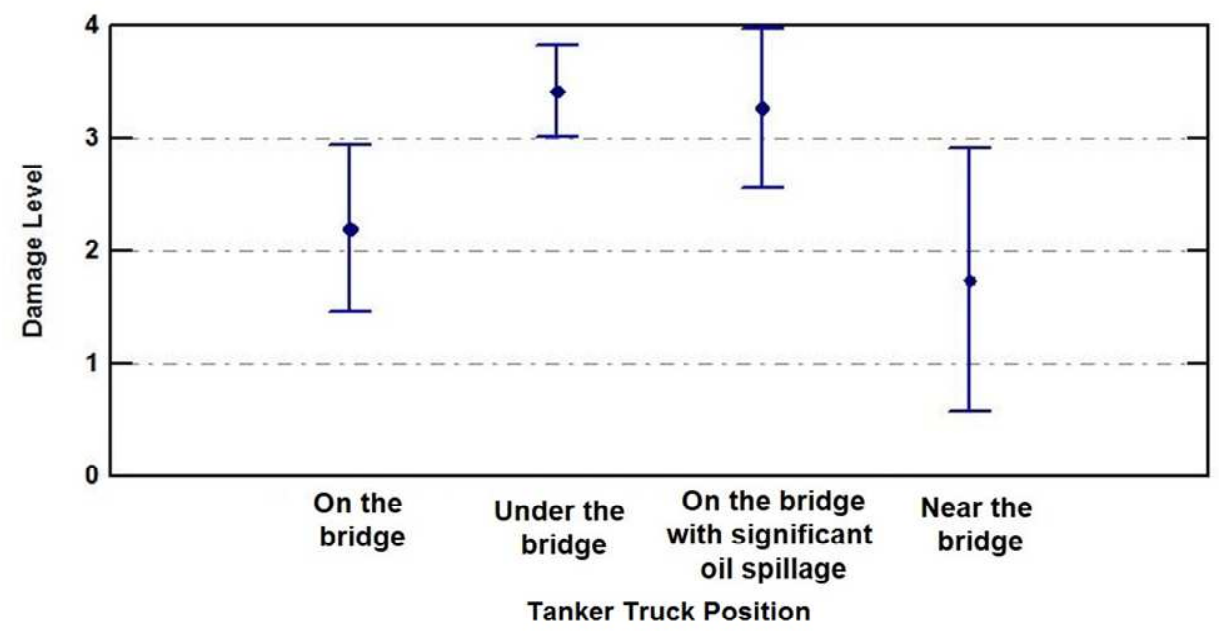

Fig. 6. Relation between the bridge damage level and the position of the tanker truck. Tukey's intervals and average damage levels.

A case in point is the fire on the Harrisburg bridge in 2013 (see Table 1), when a fuel tanker carrying diesel fuel caught fire after an accident on the lower deck. The flames reached such high temperatures around the steel beams on the upper deck that the damage was serious enough to require rebuilding the upper deck, while the lower deck only needed repairs. The Mathilde Bridge fire (see Table 1) is another example of the effects of an oil spill after a fire. The direct and indirect costs of this incident have been estimated to be $€ 18$ million (around $\$ 20.5$ million) (Le Figaro, 2015).

\section{Influence of the bridge structural system on the damage level}

Figure 7 contains a pie-chart of bridge types in bridges that sustained level 4 or 5 damage. $77 \%$ of these bridges had decks constructed with I-girders, of which $43 \%$ were composite beams, $27 \%$ concrete and $7 \%$ were of steel. 


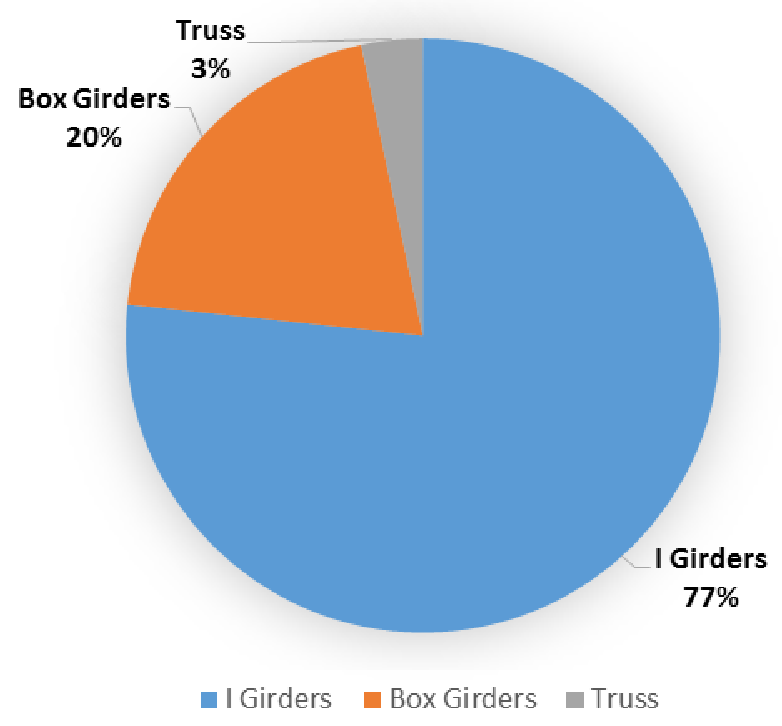

Fig. 7. Bridge fires caused by fuel tankers. Structural systems used by the bridges that sustained level 4 or 5 damage.

\section{Conclusions}

This paper proposes a method of collecting information on bridge fires and classifying the damage they sustained. It also uses statistical analysis to study the factors that influence damage levels in the information compiled from 154 cases of bridge fire events. From this study the following conclusions can be drawn:

1) Wooden bridges have a high probability of collapsing in a fire. Other materials commonly used in bridge decks have similar levels of vulnerability to fire, but much lower than wood.

2) Fires caused by tanker trucks cause the most damage, being the most harmful accidents those caused by tankers carrying gasoline, being the fuel quantities carried in the tankers in the cases analyzed between $30-35 \mathrm{~m}^{3}$.

3) Higher damage levels occur when flames and hot gases come into direct contact with the structure. This can happen when the fire is in materials stored under the bridge, when a tanker catches fire under the bridge or on top of the bridge with subsequent fuel spillage accumulating under the bridge.

4) When the fire is in stored materials, the key factors involved in damage levels are: vertical clearance between fire and bottom of the deck, calorific value of the material, and the vertical clearance between the material and the lower deck surface. 
Please cite this paper as: Peris-Sayol G, Payá-Zaforteza I, Balasch-Parisi S, Alós-Moya J. (2017). "Detailed Analysis of the Causes of Bridge fires and Their Associated Damage Levels". ASCE Journal of Performance and Constructed Facilities. Volume 31. Issue 3. June 2017. DOI:10.1061/(ASCE)CF.1943-5509.0000977

5) The site, structural system, span and width of the bridge do not have a significant influence from the statistical point of view on the bridge damage level. However, most of the bridges that collapsed or suffered severe damage due to tanker fires were built with I-girders in the structure, so that this type deserves special attention in studies on bridge fires. This fact could be due to the high number of bridges using this structural system. Special attention must also be paid in the construction phase to scaffolding and formwork when these are of wood, since they have been responsible for several fires involving severe damage.

6) To reduce the damage caused by bridge fires, the following preventive measures should be taken: (i) bridge drainage systems should be properly designed and maintained to prevent fuel spills from accumulating under the bridge, (ii) the storage of flammable materials under bridges should be forbidden, especially when the vertical clearance of the bridge is small, (iii) if a bridge is considered strategic by the authorities and there is an important traffic of tanker trucks on or under the bridge, specific studies should be carried out to ensure the adequate response of the bridge to a fire.

The results obtained in the present study can be used as a basis for identifying the different scenarios that need to be considered in estimating a bridge's fire response, and so can also be expected to be useful to engineers in charge of assessing this type of vulnerability.

\section{Acknowledgements}

The research presented in this paper is sponsored by the Spanish Ministry of Education (Research Project BIA 2011-27104). The authors also want to thank Dr. J. Glassman for providing information for the present study and Dr. V. Yepes for his assistance.

\section{References}

10 TV (2015). "Driver Cited After Tanker Carrying Ethanol Rolls Over, Sparking Massive Fire". http://www.10tv.com/ (Oct 24, 2015) 
Please cite this paper as: Peris-Sayol G, Payá-Zaforteza I, Balasch-Parisi S, Alós-Moya J. (2017). "Detailed Analysis of the Causes of Bridge fires and Their Associated Damage Levels". ASCE Journal of Performance and Constructed Facilities. Volume 31. Issue 3. June 2017. DOI:10.1061/(ASCE)CF.1943-5509.0000977

10 TV (2015). "New Traffic Pattern On I-70 at I-270 On The West Side". http://www.10tv.com/ (Oct $24,2015)$

American Association of State Highway and Transportation Officials. (2015). "LRFD Bridge Design Specifications.” 7th Edition, with 2015 Interim Revisions.

Ahram (2014). "One killed as section of bridge collapses in Cairo". http://english.ahram.org.eg/ (Oct 24, 2015)

Alos-Moya J, Paya-Zaforteza I, Garlock M.E.M., Loma-Ossorio E, Schiffner D, Hospitaler A. Analysis of a bridge failure due to fire using computational fluid dynamics and finite element models. Engineering Structures 2014; 68: 96-110.

Astaneh-Asl, A., Noble, C.R., Son, J., Wemhoff, A.P., Thomas, M.P., McMichael, L.D. (2009). "Fire protection of steel bridges and the case of the MacArthur maze fire collapse." Proc., ASCE TCLEE lifeline earthquake engineering in a multihazard environment conference, Oakland (CA), p. 1-12.

Bergerhausen, U., Priestaff, S., (2012). "Security Evaluation of Street Bridges for Fire Exposure”. In Proceedings of the 7th Security Research Conference, Future Security, Bonn, Germany, pp. 188-191. Bulwa, D, Fimrite, P. (2007). "Tanker fire destroys part of MacArthur maze." $<$ http://www.sfgate.com $>$ (April 2007)

Calderón, P.A., Adam, J.M., Payá-Zaforteza, I. (2008). "Failure analysis and remedial measures applied to a RC water tank." Engineering Failure Analysis, 16 (5), pp. 1674-1685.

Carretero-Ayuso, M., Moreno-Cansado, A., and Cuerda-Correa, E. (2015). "Research and Analysis on Recurring Anomalies in Foundations and Structures." J. Perform. Constr. Facil., 10.1061/(ASCE)CF.1943-5509.0000779, 04015037.

CBS Los Angeles (2014). “Officials Reopen All I-15 Lanes After Ranchero Road Bridge Fire”. http://losangeles.cbslocal.com/ (Oct 24, 2015)

European Committee for Standardization. (2002). "Actions on structures, part 1-2: general actions actions on structures exposed to fire". Eurocode 1, Brussels (Belgium)

European Committee for Standardization. (2003). "Actions on structures, part 2: traffic loads on bridges". Eurocode 1, Brussels (Belgium) 
Please cite this paper as: Peris-Sayol G, Payá-Zaforteza I, Balasch-Parisi S, Alós-Moya J. (2017). "Detailed Analysis of the Causes of Bridge fires and Their Associated Damage Levels". ASCE Journal of Performance and Constructed Facilities. Volume 31. Issue 3. June 2017. DOI:10.1061/(ASCE)CF.1943-5509.0000977

Chung, P., Wolfe, R.W., Ostrom, T., Hida, S. (2008). “Accelerated bridge construction applications in California - a lessons learned report." California Department of Transportation (CALTRANS), United States.

Dai, K., Wang, J., Huang, Z., and Felix Wu, H. (2015). "Investigations of Structural Damage Caused by the Fertilizer Plant Explosion at West, Texas. II: Ground Shock." J. Perform. Constr. Facil., 10.1061/(ASCE)CF.1943-5509.0000800, 04015052.

Feng, J., Cai, J. (2009). "Progressive Collapse of Cable-Stayed Bridges". International Conference on Transportation Engineering, Chengdu, China, Vol. 1, pp. 2484-2489.

Garlock, M.E., Paya-Zaforteza, I., Gu, L., Kodur, V. (2012). "Fire Hazard in Bridges: Review, Assesment and Repair Strategies.” Engineering Structures, 35, pp. 89-98.

Giuliani, L., Crosti, C., Gentli, F., (2012). "Vulnerability of bridges to fire". In Proceedings of the 6th International Conference on Bridge Maintenance, Safety and Management.

Godart, B.F., Berthellemy, J., Lucas, J.P (2015). "Diagnosis, Assessment and Repair of the Mathilde Bridge Close to Collapse during a Fire.” Structural Engineering International, 25(3) pp. 331-338

Gong, X. and Agrawal, A. (2015). "Numerical Simulation of Fire Damage to a Long-Span Truss Bridge.” J. Bridge Eng., 20(10), 04014109.

Kutner, M.H., Neter, J., Nachtsheim, C.J., Li, W. (2005). “Applied linear statistical models." McGraw-Hill Higher Education, New York, USA.

Le Figaro (2015). "Pont de Rouen: le routier ne paiera pas les dégâts." "Rouen Bridge: the truck driver will not pay the damage". http://www.lefigaro.fr (Oct. 24, 2015). In French.

Le High Valley live (2013). "I-81 near Harrisburg to be closed several days due to tanker truck fire". http://www.lehighvalleylive.com/ (Oct 24, 2015)

Lee, C. and Wang, T. (2015). "Invert Anomalies in Operational Rock Tunnels: Appearance, Causes, and Countermeasures." J. Perform. Constr. Facil., 10.1061/(ASCE)CF.1943-5509.0000726, 04015048 .

Los Angeles Times (2014). "Bridge fire leaves Hesperia plan for economic boost in ashes". http://www.latimes.com/ (Oct 24, 2015) 
Please cite this paper as: Peris-Sayol G, Payá-Zaforteza I, Balasch-Parisi S, Alós-Moya J. (2017). "Detailed Analysis of the Causes of Bridge fires and Their Associated Damage Levels". ASCE Journal of Performance and Constructed Facilities. Volume 31. Issue 3. June 2017. DOI:10.1061/(ASCE)CF.1943-5509.0000977

Mostafaei, H., Sultan, M., Kashef, A. (2014). "Resilience assessment of critical infrastructure against extreme fires." Proc., 8th International Conference on Structures in Fire, Shanghai, China, pp. 11531160.

Naser, M.Z., Kodur, V.K.R. (2015). “A probabilistic assessment for classification of bridges against fire hazard." Fire Safety Journal, 76, pp. 65-73.

NBC4 (2015). "ODOT building temporary roadway after crash damages I-70”. http://nbc4i.com/ (Oct $24,2015)$

National Fire Protection Association. (2014). "NFPA 502: Standard for road tunnels, bridges, and other limited highways." Quincy, MA, USA.

Noble, C.R, Wemhoff, A.P, McMichael, L.D. (2008). “Thermal-Structural Analysis of the MacArthur Maze Freeway Collapse”. ASME 2008 Heat Transfer Summer Conference, Jacksonville, USA. pp. $511-519$

Payá-Zaforteza, I., Garlock, M. (2012). “A numerical investigation on the fire response of a steel girder bridge." Journal of Constructional Steel Research, 75, pp. 93-103.

Peris-Sayol, G., Alós-Moya, J., Payá-Zaforteza, I., Hospitaler-Pérez, A. (2014). “A parametric study on the thermo-mechanical response of a multi-girder steel bridge submitted to real fires." Informes de la Construcción, 66 (Extra-1) (In Spanish)

Peris-Sayol, G., Payá-Zaforteza, I., Alós-Moya, J., Hospitaler, A. (2015). “Analysis of the influence of geometric, modeling and environmental parameters on the fire response of steel bridges subjected to realistic fire scenarios." Computers and Structures, 158, pp. 333-345.

Quiel, S.E., Yokoyama, T., Bregman, L.S., Mueller, K.A., Marjanishvili, S.M. (2015). “A streamlined framework for calculating the response of steel-supported bridges to open-air tanker truck fires." Fire Safety Journal, 73, pp. 63-75.

Society of Fire Protection Engineers. (2002). "Handbook of Fire Protection Engineering.” 3th Edition. NFPA, USA, ISBN 087765-451-4.

StatPoint Technologies, Inc. (2010). "STATGRAPHICS®: Centurion XVI User Manual” 
Please cite this paper as: Peris-Sayol G, Payá-Zaforteza I, Balasch-Parisi S, Alós-Moya J. (2017). "Detailed Analysis of the Causes of Bridge fires and Their Associated Damage Levels". ASCE Journal of Performance and Constructed Facilities. Volume 31. Issue 3. June 2017. DOI:10.1061/(ASCE)CF.1943-5509.0000977

The New York Times (2006). "Tanker Explosion Shuts Down Queens Highway and Subway" http://www.nytimes.com/ (Oct. 24, 2015)

The Sentinel (2013). "PennDOT: Insurance won't recoup I-81 tanker crash costs" http://cumberlink.com/ (Oct 24, 2015)

The Tennessean (2014). "I-65 closed this weekend for repairs at explosion site". http://www.tennessean.com/ (Oct 24, 2015)

The Tennessean (2014). "I-65 lanes to close most of next week for bridge removal". http://www.tennessean.com/ (Oct 24, 2015)

Wright, W., Lattimer, B., Woodworth, M., Nahid, M., Sotelino, E. (2013). "Highway Bridge Fire Assessment Draft Final Report." Prepared for the NCHRP Program Transportation Research Board of the National Academies, Virginia Polytechnic Institute and State University.

WSMV (2014). "Tanker truck driver killed in crash, explosion on I-65 in Franklin". http://www.wsmv.com/ (Oct 24, 2015)

Yahoo News (2014). "Fire collapses overpass in Cairo, kills policeman". https://news.yahoo.com/ (Oct 24, 2015) 